\title{
Growth and Income Distributions in Four EU Economies
}

\author{
Keshab Bhattarai ${ }^{1}$
}

Published online: 27 June 2016

(C) The Author(s) 2016. This article is published with open access at Springerlink.com

\begin{abstract}
Dynamic multi-sectoral and multi-household general equilibrium models are constructed to show how the economies of Germany, France, Spain and the United Kingdom will evolve from 2006 to 2090. These models generate dynamic paths of investment and capital accumulations, demand and supply across production sectors, consumption and welfare of households, relative prices of goods and services, revenue and expenditure of governments, exports, imports, and trade balance consistent with the dynamic general equilibrium in these economies. The models show that inequalities in income distribution among households will not decrease but widen if the current mix of direct and indirect taxes continues in all four countries. Growing inequalities in these economies justify further investments in education and skills.
\end{abstract}

Keywords Growth · Redistribution · European Union · General equilibrium

JEL Classification $\mathrm{C} 68 \cdot \mathrm{D} 63 \cdot \mathrm{O} 15$

\section{Introduction}

Macroeconomic stability, higher economic growth, greater efficiency in allocation of resources and more equal distributions of peace and prosperity are building blocks of the European economic policy. From the Treaty of Rome in 1957 to the adoption of the Lisbon Agenda in 2000, the European Union (EU) made significant improvements in integration among its 28 member countries. Europe is becoming a more powerful,

This paper was presented at the $80^{\text {th }}$ International Atlantic Economic Conference in Boston, 8-11 October 2015. An earlier version of this paper was presented at the International Conference on Policy Modeling - EcoMod2009, Ottawa, Canada, June 24-26, 2009.

Keshab Bhattarai

K.R.Bhattarai@hull.ac.uk

1 Business School, University of Hull, Hull HU6 7RX, UK 
dynamic and vibrant region in the global economy. Growth and redistribution analyses for the EU's four big economies, France, Germany, Spain and the UK, that represent about 250 million people or $50 \%$ of the EU's 500 million population, are presented here based on results of the dynamic general equilibrium models of these economies. These complement several studies relating to the single market project for European integration.

For instance, Allen et al. (1998) applied inputs from an econometric model to a computable general equilibrium (CGE) model to assess the direct effect of reduction in trade barriers under the single market project (SMP). Their conclusion, that the SMP had pro-competitive impacts and not only the nature but also the intensity of competition has increased in various industries in the EU, has sound theoretical bases. Baldwin et al. (1997) estimated costs and benefits of joining the EU and argued that risk premium of investment has reduced significantly after the implementation of the EU enlargement project. Their CGE model contained scale economies and DixitStiglitz type monopolistic competition. It was calibrated to the Global Trade Analysis Project (GTAP) database.

Broer et al. (1994), using a small open economy model, analysed how reducing the burden of income taxes and pay as you go (PAYG) contributions from labour income can improve labour supply, generate more efficiency incentives and guarantee a Pareto improvement. Francois (1996) illustrated how a higher rate of population growth in developing countries can erode real wages in developed countries in factor-based trade models and two-way trade based on product differentiation. Haaland (1992) found the 1992 SMP to have positive impact through enhancement of capital accumulation. Harrison et al. (1997) computed benefits of the Uruguay round of trade negotiation between $\$ 96$ to $\$ 171$ billion in a GE model of 24 regions and 22 commodities. Haaland et al. (1987) study comparative advantage under the Ricardo-Hecksher-Ohlin-Jones framework in six regional global economy models.

Jensen and Rutherford (2002) explained how public debt reduction achieved through spending cuts hurts elderly poor. Public goods and transfers provided by the surplus generated by debt reduction would benefit future poor. For them intergenerational equity is likely to pose a threat to the fiscal consolidation that is less likely to occur.

Keuschnigg et al. (1996), in an overlapping generation model, evaluated access into the EU which affects expected capital accumulation, saving and investment activities, trade integration and effects of adoption of common agricultural policies. The net gains are around $1.24 \%$ of GDP. The accession treaty favours future generations at the cost of the current generation (Kotlikoff 1998).

Nordhaus and Yang (1996) presented a regional integration model of climate change and the economy considering pure market solutions, efficient cooperative outcomes and non-cooperation equilibrium. Emission is controlled more under the cooperation rather than in the non-cooperative solution, though high income countries may be the major losers from cooperation.

Piazolo (2001) incorporates the adjustment cost of investment in order to capture the non-steady state phenomenon in the benchmark in a standard CGE model. Saito (2004) illustrated how estimation of elasticities of substitution become different when estimated with bilateral rather than multilateral data. Wren-Lewis et al. (1996) compare an econometric macroeconomic model to a simpler theoretical model and continue perturbations until properties match between econometric and theoretical models for analysis of fiscal policy under the COMPACT structural econometric model. Wright 
(1988) studies the stochastic economy with labour contracts with overlapping generations and finite horizon employers to reconcile data with equilibrium theory. Krusell et al. (2000) show how skill biased technological changes are the main reasons for the rising gap in wages of skilled and non-skilled workers. Despite so much work on the European economies ${ }^{1}$ it is hard to find applied dynamic general equilibrium models in the literature appropriate for analysing growth prospects in a multi-household multi-sectoral setup. We develop a dynamic multi-household multisectoral dynamic general equilibrium model of four EU economies in which households are differentiated by their labour and income categories and vary in their consumption patterns in order to fulfil this gap in the literature.

\section{Introduction to Dynamic General Equilibrium Models}

Applied dynamic general equilibrium models of four EU economies presented here are based on intertemporal optimisation decisions of households and firms. In each period, demand for goods and services is derived from preferences subject to lifetime budget constraints of households. The supply side is derived from the profit maximisation decisions of firms. The interaction of these economies into the global economy is through exports and imports in which balance of payments are maintained through adjustments in the exchange rates. The price system allocates resources efficiently in each period and over time. All economic agents do the best they can within their intertemporal budget constraints. Computable general equilibrium models like this include most of the theoretical developments in economics over the last 200 years.

The model for each economy is benchmarked to the micro-consistent data set for the economy. Producers supply goods and services for domestic and foreign markets. Public sectors use tax and transfer policies and provide public services. The model assesses equilibrium that emerges from various policy instruments available to the policy makers. It is a fairly decentralised model aimed to replicate production and consumption activities of both the private and the public sectors. Each category of household is constrained by resources in optimizing choices. Firms are constrained by available technology in supplying commodities that are in demand in their own markets. Revenue and expenditure accounts of governments and exports and imports are balanced over time.

\section{Demand Side of the Economy}

Households differ in their preferences for goods and services and in their endowments of labour and capital. They pay taxes on labour and capital income and receive transfer payments from the government on the means-tested basis. Demand functions are schedules showing what households would like to buy with their income at given prices. These are influenced by income and substitution effects of price changes over the model horizon. In the current context, households are myopic and base their

\footnotetext{
${ }^{1}$ This is just an indication of related studies. Many other studies such as Bhattarai et al. (2015); Abrego and Whalley (2000); Armington (1969); Bhattarai (2007); Bhattarai and Whalley (2003); Edwards and Whalley (2007); Haskel (2001); Winchester et al. (2006) and Wright (1988) have modelled this issue from many different angles.
} 
decisions on lifetime income. They take prices of commodities as a given and use the benchmark interest rate in order to discount their future earnings to obtain the present value of life time income.

Utility in each period is a nested function. Consumption goods consist of constant elasticity of substitution (CES) aggregation of commodities. Household utility is derived from composite consumption goods as well as leisure in each period. The marginal rate of substitution among commodities and between composite consumption goods and leisure are influenced by the elasticity of substitution at the relevant nests of the utility function. Similarly to the inter-temporal choices, consumption today versus consumption in the future and work or leisure today versus that of tomorrow are determined to a great extent by these elasticity parameters. Markets are more flexible when the values of these elasticities are higher than when they are lower. The impact of public tax and subsidy programmes in consumption and income inequalities depends to a large extent on these parameters.

In the current context, the model decomposes the household sector of these four economies by their income deciles. In this ranking the $\mathrm{H} 1$ household is the poorest and $\mathrm{H} 10$ the richest in terms of income. All remaining households are categorised in that order. Allocations between current and future consumption of these households are influenced by the elasticity of inter-temporal substitution between consumption and leisure. Economic theory cannot predict precisely how a household responds to an increase in the wage rate as the income and substitution effects move in opposite directions.

Demand for inputs, labour, capital and technology is derived from the demand for products. When demand for a product rises, it raises its own price and further causes an increase in the demand for labour and capital in that sector.

\section{Supply Side of the Economy}

Firms behave competitively in these economies. They take prices of inputs and outputs as given and employ factors up to a point where the marginal productivity of that factor equals its remuneration. Production technology shows how inputs are transformed into output. More efficient technology generates more output from the given inputs. In general the level of technology is an outcome of the process of accumulation of human and physical capital. Further education generates more skills and skilled workers are more productive than less skilled workers.

\section{Trade and Aggregate Supply}

A system of free trade allows economies to export goods in which each economy has a more comparative advantage and imports goods which are not in adequate supply in the home economy. Real exchange rates are determined by ratios of average prices of tradable commodities at home and abroad. Households in an economy can raise their welfare by exporting goods which they can produce more efficiently and by importing goods which they cannot produce efficiently at the home country.

Production and aggregate supply of these model economies are represented by a set of nested functions. Initially labour and capital inputs determine the value added for a given sector. Inter-industry linkages are given by the coefficients of the input-output table. The 
gross output of any sector can be exported to foreign markets or supplied to domestic markets. Following a standard Armington product differentiation, imported goods compete with domestic products in forming the aggregate supply of the economy. Volumes of exports and imports balance for each period or intertemporally over the model horizon.

\section{Public Sector}

Governments provide public goods and transfer income to households collecting revenue from direct and indirect taxes, though former ones are more important than later ones in these economies. Social insurance is provided to low income households who are vulnerable to market conditions. Impacts of public programmes on the welfare of households are measured in terms of money metric utility functions. The income gap between the rich and poor households may be higher without transfer programmes or without good provision of public services such as education and health. Our model is more comprehensive than Gottardi et al. (2015) who suggest that linear optimal taxes on both capital and labour determine the optimal level of debt when individuals face uninsurable risks to accumulation of their human capital. Chen (2015) analyzes how the degree of price rigidity or price flexibility, linked to the degree of market completion for production firms that consider durability, production and production periods in determining prices, is applicable to the current model with more centralized structure for fiscal policy.

\section{Markets and the Relative Prices}

Markets determine prices by reconciling demand for products by households to the supply of commodities by firms and demand for inputs by firms to the supply of factors by the owners of factor services. Prices adjust until these demands equals the supplies. Markets clear dynamically in the sense that the demand for products by households equals supply of products by firms and saving by households equals investment by firms. Allocations are Pareto optimal. There is no alternative allocation which can make an economic agent better off without making another worse off. Public sector tax and

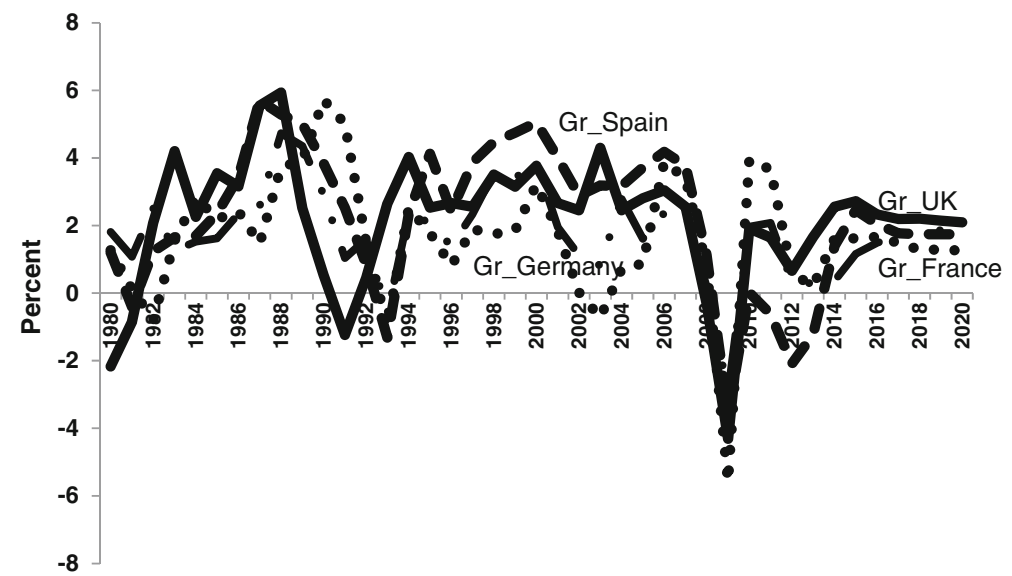

Fig. 1 Growth rates in France, Germany, Spain and the UK (data source: IMF) 


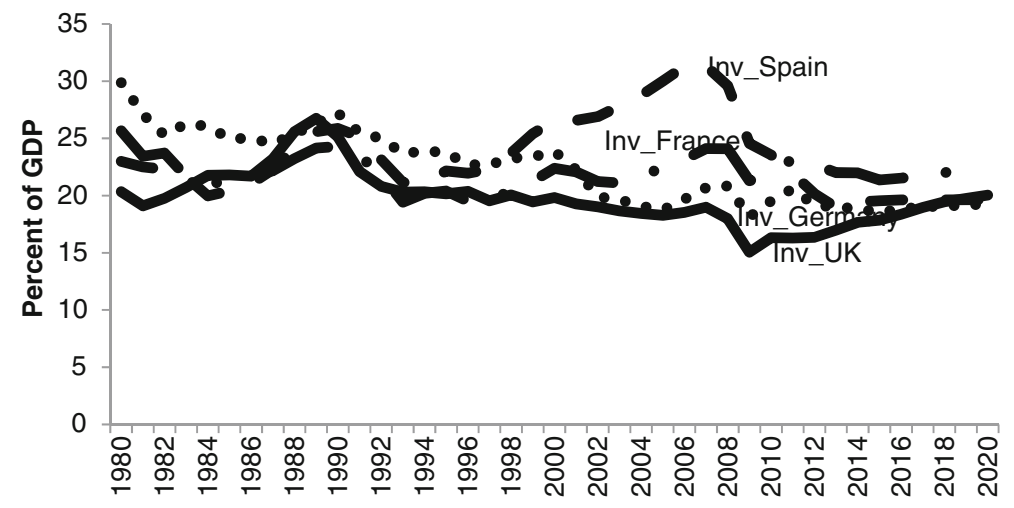

Fig. 2 Ratios of investment to GDP in four EU economies (data source: IMF)

transfer policies impact on households' income through their affect these relative prices.

\section{Macro Trends and Micro-consistent Benchmark Data Set}

Macroeconomic fluctuations are commonly observed in terms of growth, rates of GDP, and investment ratios as shown in Figs. 1 and 2. The major challenge for an economy is to contain these fluctuations to a reasonable degree and ensure that economies are able to move off the transitional dynamics toward the steady state.

Next we examine macroeconomic trends for each of these four economies along with the micro-consistent data for each required to benchmark the dynamic economy.

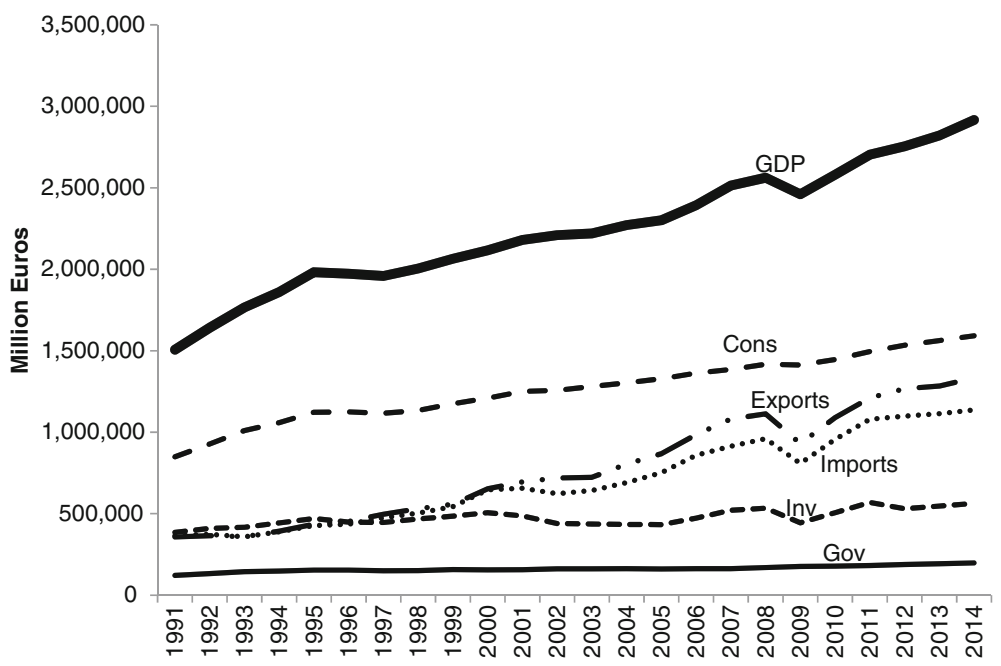

Fig. 3 Macroeconomic trends of Germany; (data source: Eurostat) 


\section{Germany}

After successful decades of speedier economic growth, the German economy slowed down in mid 1990s (Fig. 3). Unemployment rate is around $5.1 \%$ of the workforce. Financial troubles have affected the flow of credits recently. The unit labour costs are rising. There were fluctuations in construction activities and housing markets. A slowdown of exports occurred because of appreciation of the Euro relative to other major currencies that made the German economy less competitive in the world. Reduction in global demand also posed threats to economic growth. While rising food and energy prices are likely to keep upward pressures on inflation, there are concerns regarding rising wage inequality due to massive skill gaps among workers. The dynamic general equilibrium model of Germany considers these realities and builds on the micro-consistent data set from the input-output (IO) table of Germany from the Organisation for Economic Co-operation and Development (OECD) (2006). Service sectors comprise around $60 \%$ and the manufacturing sectors are around $20 \%$ of the economy with private services at $16 \%$, tourism-hotel and restaurants $13 \%$, finance and real estate $10 \%$, business services $11 \%$ and transport and communication $6 \%$. The input-output table shows how various sectors of the German economies are related to each other. The technology transaction matrix shows inter-sectoral input-output linkages. The value added and the final demand parts in the IO table give the functional distribution of income and consumption patterns across households.

\section{France}

The service sector constitutes about $58 \%$ and the manufacturing about $30 \%$ of French GDP. The wage income in the private and business services are much higher than other sectors as a proportion of the GDP. More than $50 \%$ of national income goes to households in the top three deciles. Uncertainty in housing and financial markets has slowed down growth rates of output and the rate of job creation in France in recent years. While the upward pressures in wage rates have raised unit labour costs, these also have reduced the rate of employment creation. Net exports are falling because of the slowdown in global demand and erosion of competitiveness due to appreciation of the Euro. Raising the rate of productivity growth and enhancing the skill of the work force, the major agenda for labour market reforms seem well placed.

\section{Spain}

The spanish economy has a relatively larger manufacturing sector (46\%) and smaller services sector $(35 \%)$ than of the other three economies. Income and wage distributions are more unequal. Spain enjoyed relatively stable growth in output in the last decade despite a higher rate of unemployment. However, recent tormoil in financial and housing markets is leading Spain towards diminished expectations not only arising from a global recession but also due to lower rates of job creation, higher trade deficits, higher rates of expected inflation and pressure on the public budget. 
Table 1 Elasticities, growth and interest rates for the benchmark reference path

\begin{tabular}{lr}
\hline Parameters & Values \\
\hline Elasticity of substitution & 1.5 \\
Steady state growth rate of output & 0.03 \\
Benchmark interest rate & 0.05 \\
Rate of depreciation & 0.03 \\
Intertemporal substitution elasticity & 0.95 \\
Elasticity of substitution on capital and labour & 1.5 \\
Armington elasticities & 1.2 \\
Household income tax rates (vary by household) & 0 to 0.55 \\
Elasticity of substitution in public consumption & 1.5 \\
\hline
\end{tabular}

Source: Elasticities are based on Bhattarai (2015) and tax rates on input-output tables from the OECD (2006)

\section{The United Kingdom}

The growth rate of output and creation of employment have been smooth and uninterrupted in the UK in the last 15 years particularly after the operational independence of the Bank of England on monetary policy with a clear mandate of stabilising the price level in 1997. New deal programs and education and employment policies were successful in creating jobs though there were some concerns regarding the rising gaps between wages of skilled and unskilled workers in recent years. The UK economy is dominated by service sectors which account for around $65 \%$ of total economic activities, with private services at $18 \%$, tourism-hotel and restaurants $15 \%$, finance and real estate $12 \%$, business services $11 \%$ and transport and communication $8 \%$. Wage distributions are

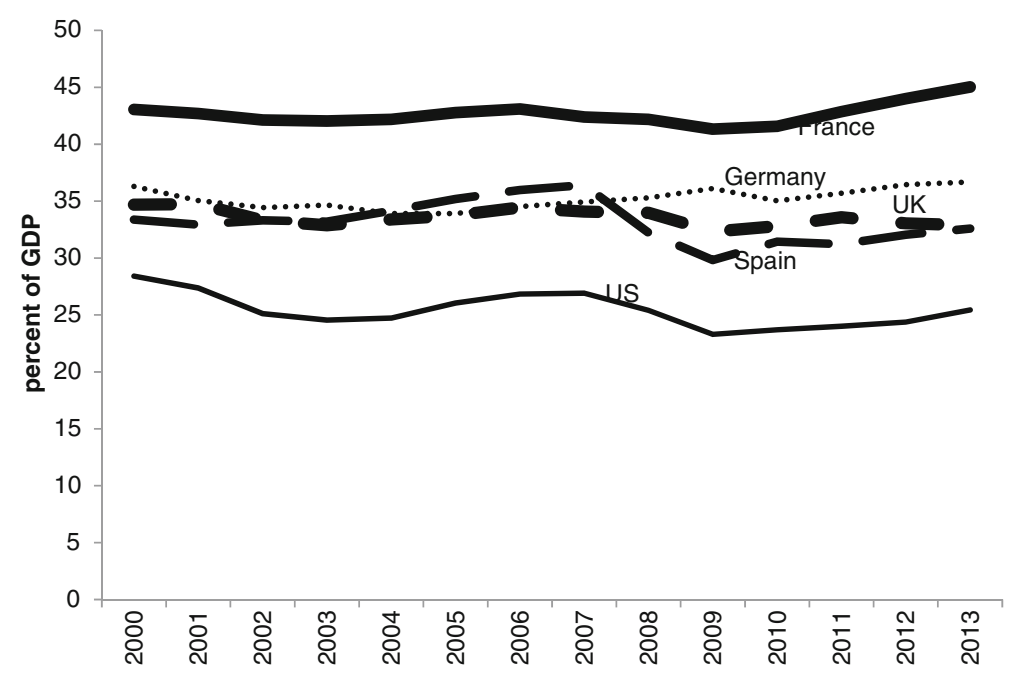

Fig. 4 Total tax revenue ratio to the GDP (data from the OECD) 
Table 2 Tax rates on capital and labour inputs by sectors in model economies

\begin{tabular}{|c|c|c|c|c|c|c|c|c|}
\hline & \multicolumn{2}{|l|}{ UK } & \multicolumn{2}{|c|}{ Germany } & \multicolumn{2}{|l|}{ France } & \multicolumn{2}{|l|}{ Spain } \\
\hline & Capital & Labour & Capital & Labour & Capital & Labour & Capital & Labour \\
\hline Primary & 0.01 & 0.13 & 0.01 & 0.13 & 0.01 & 0.13 & -0.02 & -0.18 \\
\hline Manufacturing & 0.06 & 0.08 & 0.06 & 0.11 & 0.06 & 0.11 & -0.07 & -0.10 \\
\hline Material Manuf. & 0.09 & 0.07 & 0.10 & 0.19 & 0.10 & 0.19 & 0.01 & 0.02 \\
\hline Machinery manuf. & 0.09 & 0.07 & 0.15 & 0.18 & 0.15 & 0.18 & 0.01 & 0.01 \\
\hline Utility & 0.07 & 0.40 & 0.07 & 0.24 & 0.07 & 0.24 & 0.00 & -0.01 \\
\hline Construction & 0.05 & 0.13 & 0.09 & 0.14 & 0.09 & 0.14 & 0.02 & 0.03 \\
\hline Tourism hotel rest. & 0.09 & 0.13 & 0.07 & 0.10 & 0.07 & 0.10 & 0.01 & 0.04 \\
\hline Transport /Comm. & 0.09 & 0.12 & 0.08 & 0.13 & 0.08 & 0.13 & 0.02 & 0.07 \\
\hline Finance/Real Est. & 0.02 & 0.13 & 0.03 & 0.30 & 0.03 & 0.30 & 0.02 & 0.22 \\
\hline Business Services & 0.04 & 0.06 & 0.05 & 0.08 & 0.05 & 0.08 & 0.01 & 0.02 \\
\hline Professional Serv. & 0.06 & 0.04 & 0.07 & 0.05 & 0.07 & 0.05 & 0.06 & 0.04 \\
\hline
\end{tabular}

Source: The production tax rates were calculated from the input-output tables from the OECD (2006) for each country

more unequal across sectors and across households in comparison to Germany, France and Spain.

As illustrated above, the micro-consistent data for the dynamic general equilibrium model is constructed from the input-output table for 2006 (OECD 2006). The distribution of income across households and their consumption patterns had to be based on the data from the World Bank.

Model computations require values of behavioural elasticities and policy parameters. As in other dynamic CGE models, central values of elasticity parameters are based on

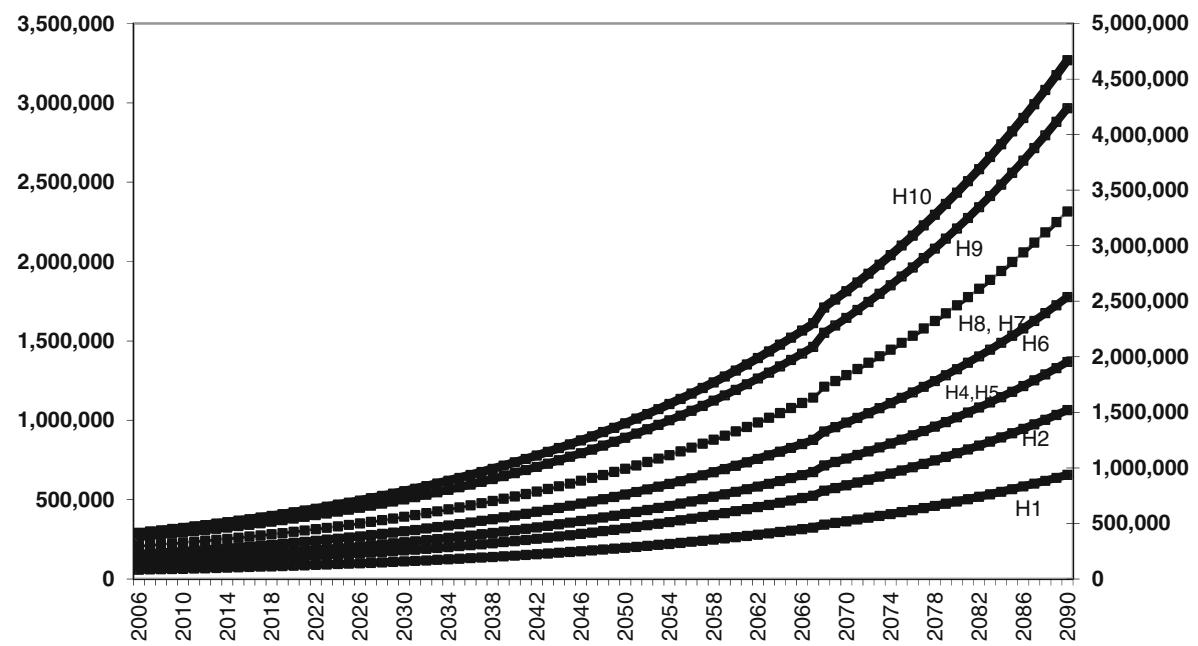

Fig. 5 Utility distribution paths among German households (Euro): Dynamic CGE results. Labels H1, $\mathrm{H} 2, .,{ }_{,},, \mathrm{H} 10$ refer to utility paths of the poorest to the richest households respectively. This model was benchmarked to the input-output table of Germany from the OECD (2006) 


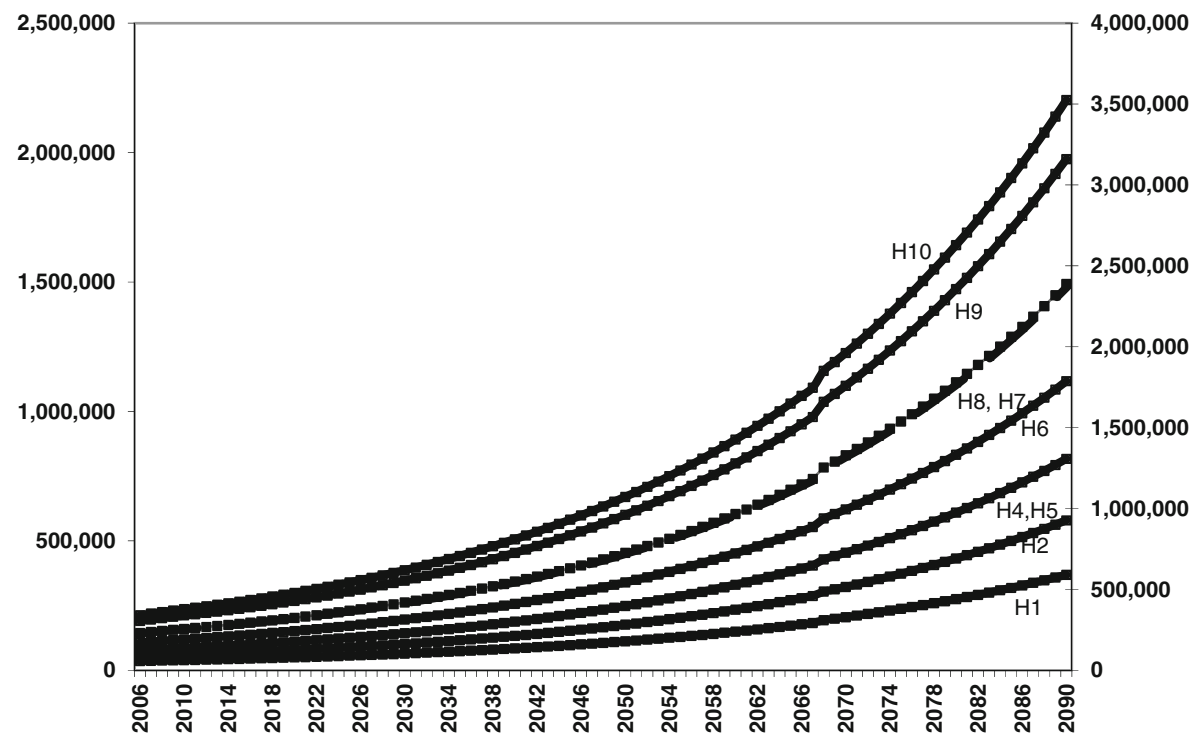

Fig. 6 Utility distribution paths among French households (Euro): Dynamic CGE results Labels H1, $\mathrm{H} 2, .,,,, H 10$ refer to utility paths of the poorest to the richest households respectively. This model was benchmarked to the input-output table of France from the OECD (2006)

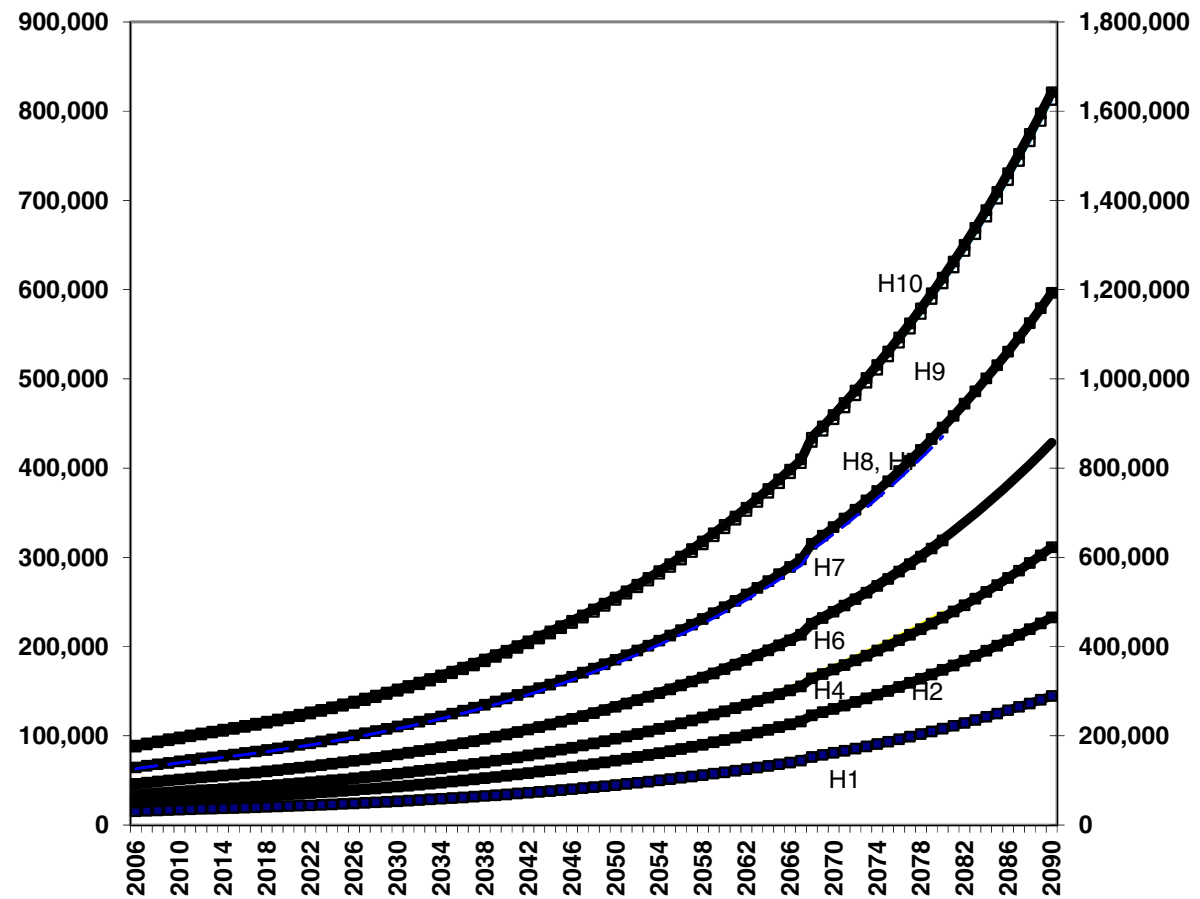

Fig. 7 Utility distribution paths among Spanish households (Euro): Dynamic CGE results. Labels H1, $\mathrm{H} 2, .,,,, H 10$ refer to utility paths of the poorest to the richest households respectively. This model was benchmarked to the input-output table of Spain from the OECD (2006) 


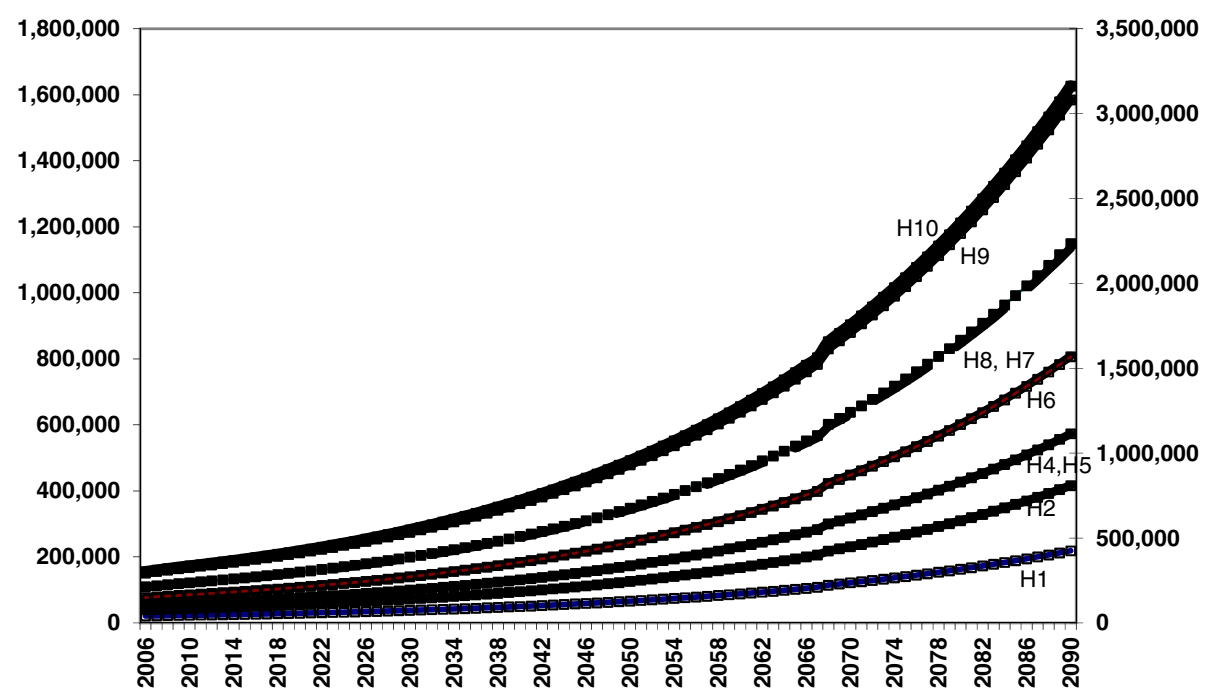

Fig. 8 Utility distribution paths among UK households (£): Dynamic CGE results. Labels H1, H2,.,,,,,H10 refer to utility paths of the poorest to the richest households respectively. This model was benchmarked to the input-output table of the UK from the OECD (2006)

the literature (Table 1). Tax revenue ratios across these countries are shown in Fig. 4 and tax rates on capital and labour inputs are given in Table 2.

This model contains more details on data series and input-output tables used for construction of the benchmark steady states for these economies. These are skipped here for space reasons. Here a $20 \%$ of corporate income tax and a $30 \%$ of labour income tax replace the existing labour and capital income taxes in the counterfactual scenarios. This harmonises the tax structures in these four economies to reforms in the fiscal policies in these economies.

\section{Analysis of Dynamic CGE Model Results on Growth and Redistribution}

Dynamic general equilibrium models presented here show how these four economies evolve from 2006 to 2090. The rate of investment and accumulation of capital, level of production among all sectors, consumption and welfare of households, relative prices of goods and services, revenue and expenditure of the public sectors, exports, imports and net trade balance are consistent with the equilibrium path. However these are alarming in that inequality in the distribution of income (utility from consumption and leisure) among households will not decrease but widen if the current policies continue not only in Germany but also in France, Spain and the UK. These economies tend to converge in the pattern of inequality because of skill-biased technical progress in these market economies. This explains why education and skill formation were at the centre of the Lisbon growth agenda.

The time profile for distribution of utility across household deciles (H1, H2,..,,,,H10) clearly shows that the inequality will rise in coming decades not only in Germany but also in France, Spain and UK (Figs. 5, 6, 7 and 8). In fact these economies tend to converge in the pattern of inequality. Readers, however, should be aware of limitations 


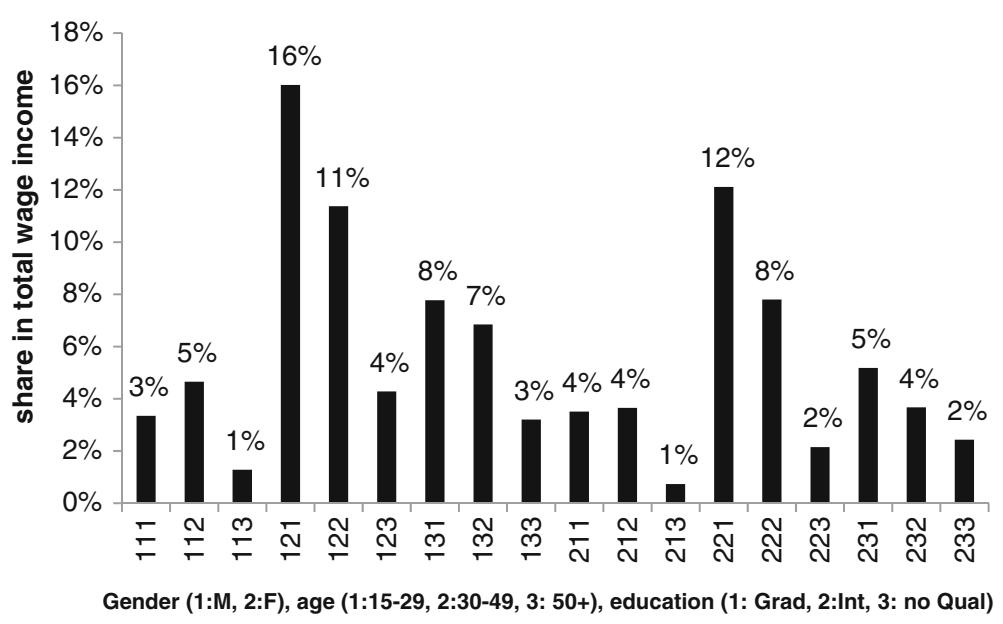

Fig. 9 Wage share by gender, age and education in the UK (Data source: EUKLEMS)

in these long-run simulations. The underlying reference path of the quantity variables is driven by the exogenous growth rate of the population. The reference paths of relative prices depend on the benchmark rate of return. Despite these limitations, we are able to show clearly that long-run problems of growth and redistribtuion require long-run solutions. Well-designed fiscal policies can be the solutions.

It is also importat to relate very intuitive results of the dynamic CGE models above of four EU economies to the literature. Skill premium has been causing greater inequality around the world since the 1980s in the labour market (Krusell et al. 2000). Accumulations of capital continue till the rates of return on capital are greater than the underlying growth rates of the economies (Piketty 2014). Thus our results also show that skill-biased technical progress and application of more sophisticated capital instruments in production create huge gaps in the level of income of low and high income individuals. Further these inequalities may have intergenerational aspects because of skill differences, assortative matching, social security and the time preferences as often found in the OLG model with bequests (Gokhale et al. 2001). This means children of rich parents remain rich. Such vicious circles in inequality can be broken only by means of quality education. By implications of our analysis we recommend greater access to quality education in all economies consistent with the Lisbon growth agenda launched in 2020.

One often forgotten point in this respect is the link between education and economic freedom and economic wellbeing. A high level of education not only improves the degree of economic freedom but also enhances economic wellbeing (Belasen and Hafer 2013). Freedoms of investment, corruption, government size, property rights and trade lead to an increase in GDP and higher per capita income (Cebula et al. 2013). Skill enhancing technology promotes growth more than technical advancement in the final goods production sector (Basu and Bhattarai 2012). Replacement of existing taxes by the flat tax can reduce inequality (Bas et al. 2010. In theory equilibrium manifolds not only relate to endowments of skills (Balasko 2015) but also to the right level of education as a Condorcet winner policy alternative (Pivato (2015)). Further empirical evidence of our findings can be found in the EUKLEMS data series on wage shares. 
Males and females of middle age with university degrees earn $16 \%$ or $12 \%$ of the total wage bill in contrast to $4 \%$ and $2 \%$ of their counterparts with no education, respectively, (Fig. 9).

Inequalities may persist and affect households if regulators do not understand the market power and the effects of policy interventions. As Tirole (2015) mentions "competition is rarely perfect, markets fail and market power...must be kept in check." Life cycle choices of individuals regarding consumption and savings that evolved based on Cambridge growth models in the 1960s also affect inequality (Deaton (2015)). These inequalities caused either by market power or by life cycle choices could be corrected by the right set of education in these four economies and around the world.

\section{Conclusions}

Dynamic multi-sectoral and multi-household general equilibrium models are constructed to show how the economies of Germany, France, Spain and the UK will evolve from 2006 to 2090. These models were calibrated to the micro-consistent dataset obtained from the IO tables from the OECD and using the literature-based elasticities of substitution in consumption, production and trade. Tax rates on capital and labour inputs from the IO tables are complemented by time series on revenue ratios from the OECD. The models generate dynamic paths of investment and capital accumulations, demand and supply across production sectors, consumption and welfare of households, relative prices of goods and services, revenue and expenditure of governments, exports, imports and trade balance consistent to the dynamic general equilibrium in these economies. The results show that inequalities in the distribution of income among households will not decrease but widen if the current mix of direct and indirect taxes continues in all four countries. Growing inequalities in these economies justify further investments in education and skills. Wage shares in the EUKLEMS data series show that more educated workers earn more irrespective of their gender or age.

Open Access This article is distributed under the terms of the Creative Commons Attribution 4.0 International License (http://creativecommons.org/licenses/by/4.0/), which permits unrestricted use, distribution, and reproduction in any medium, provided you give appropriate credit to the original author(s) and the source, provide a link to the Creative Commons license, and indicate if changes were made.

\section{References}

Abrego, L., \& Whalley, J. (2000). The choice of structural model in trade-wages decompositions. Review of International Economics, 8(3), 462-477.

Allen C, M. Gasiorek, A. Smith, H. Flam, P.B. Sørensen (1998) The Competition Effects of the Single Market in Europe, Economic Policy, 13:27 441-486

Armington, P. S. (1969). A theory of demand for products distinguished by place of production. IMF Staff Papers, 16, 159-176.

Balasko, Y. (2015). Wealth concerns and equilibrium. Journal of Mathematical Economics, 59(2015), 92-101. 
Baldwin, R. E., Francois, J. F., Portes, R., Rodrik, D., \& Székely, I. P. (1997). The Costs and Benefits of Eastern Enlargement: The Impact on the EU and Central Europe. Economic Policy, 12(24), 125-176.

Bas Jacobs, Ruud A. de Mooij and Kees Folmer (2010) Flat income taxation, redistribution and labour market performance, Applied Economics, 42:25, 3209-3220

Basu P. and K. Bhattarai (2012) Cognitive Skills, Openness and Growth, the Economic Record, 88: 280: March, 18-38

Belasen, A. R., \& Hafer, R. W. (2013). Do changes in economic freedom affect well-being? Journal of Regional Analysis and Policy, 43(1), 56-64.

Bhattarai, K. (2007). Economic models of hull and Humber region. Atlantic Economic Journal, 35, 473-490.

Bhattarai, K. (2015). Financial deepening and economic growth. Applied Economics, 47(11), 1133-1150.

Bhattarai, K., \& Whalley, J. (2003). Discreteness and the Welfare Cost of Labour Supply Tax Distortions. International Economic Review, 44(3), 1117-1133.

Bhattarai, K., Haughton, J., \& Tuerck, D. (2015). Fiscal policy, growth and income distribution in the UK. Applied Economics and Finance, 2(3), 20-36.

Broer D.P., W.M.T. Westerhout, A. L. Bovenberg (1994) Taxation, Pensions and Saving in a Small Open Economy, Scandinavian Journal of Economics, 96 : 3, Tax Policy in Small Open Economies, Sep.; 403424

Cebula, R. J., Clark, J. R., \& Mixon, F. G. (2013). The impact of economic freedom on per capita real GDP: a study of OECD nations. Journal of Regional Analysis and Policy, 43(1), 34-41.

Chen, G. R. (2016). Dynamic model for market competition and price rigidity. Applied Economics, 48(36), 3485-3496.

Deaton A (2015) Measuring and understanding behavior, welfare and poverty, Nobel lecture, Stockhom, 8 December. https://www.nobelprize.org/nobel_prizes/economic-sciences/laureates/2015/deaton-lectureslides.pdf

Edwards TH, Whalley J (2007) Short- and long-run decompositions of UK wage inequality changes, Bulletin of Economic Research, 59(1): 1-24.

Francois, J. F. (1996). Trade, Labour Force Growth and Wages. The Economic Journal, 106(439), 1586-1609.

Gokhale, J., Kotlikoff, L. J., Sefton, J., \& Weale, M. (2001). Simulating the transmission of wealth inequality via bequests. Journal of Public Economics, 79, 93-128.

Gottardi, P., Kajii, A., \& Nakajima, T. (2015). Optimal taxation and debt with uninsurable risks to human capital accumulation. American Economic Review, 105(11), 3443-3470.

Haaland, J. I. (1992). Comparative advantage, Terms of Trade and Welfare Effects of European Integration: Some Preliminary Assessments. Scandinavian Journal of Economics, 94(3), 373-391.

Haaland JI, VD Norman, T Wergeland and TF Rutherford (1987) VEMOD: A Ricardo-Heckscher-OhlinJones Model of World Trade, The Scandinavian Journal of Economics, 89:3, Modelling Trade and Trade Policy; 251-270

Harrison, G. W., Rutherford, T. F., \& Tarr, D. G. (1997). Quantifying the Uruguay Round. The Economic Journal, 107(444), 1405-1430.

Haskel J, and M.J. Slaughter (2001). Trade, technology and UK wage inequality, The Economic Journal 163187.

Jensen, S. E. H., \& Rutherford, T. F. (2002). Distributional Effects of Fiscal Consolidation. The Scandinavian Journal of Economics, 104(3), 471-493.

Keuschnigg, C., Kohler, W., Casella, A., \& Sapir, A. (1996). Austria in the European Union: Dynamic Gains from Integration and Distributional Implications. Economic Policy, 11(22), 155-211.

Kotlikoff LJ (1998) The AK Model: It's Past, Present, and Future, NBER Working Paper 6684.

Krusell, P., Ohanian, L. E., Ríos-Rull, J. V., \& Violante, G. L. (2000). Capital-skill complementarity and inequality: a macroeconomic analysis. Econometrica, 68(5), 1029-1053.

Nordhaus, W. D., \& Yang, Z. (1996). A Regional Dynamic General-Equilibrium Model of Alternative Climate-Change Strategies. American Economic Review, 86(4), 741-765.

OECD (2006). Input-output tables (2006 edition). Retrievable from the Internet: http://www.oecd-ilibrary.org/ industry-and-services/data/stan-input-output/input-output-database_data-00650-en

Piazolo, D. (2001). Investment Behaviour in Transition Countries and Computable General Equilibrium Models,. Applied Economics, 33(7), 829-837.

Piketty, T. (2014). Capital in the twenty-first century. Cambridge Mass: Harvard University Press.

Pivato, M. (2015). Condorcet meets Bentham, Journal of Mathematical Economics, 59 92-101

Saito, M. (2004). Armington Elasticities in Intermediate Inputs Trade: A Problem in Using Multilateral Trade Data. Canadian Journal of Economics, 37(4), 1097-1117.

Tirole, J. (2015). Market failures and public policy. American Economic Review, 105(6), 1665-1682. 
Winchester, N., Greenaway, D., \& Reed, G. V. (2006). Skill classification and the effects of trade on wage inequality. Review of World Economics, 142(2), 287-306.

Wren-Lewis S, J. Darby, J. Ireland J, O. Ricchi (1996) The Macroeconomic Effects of Fiscal Policy: Linking an Econometric Model with Theory, The Economic Journal,106:436, 543-559

Wright, R. D. (1988). The Observational Implications of Labor Contracts in a Dynamic General Equilibrium Model. Journal of Labor Economics, 6(4), 530-551. 